\title{
Synthesis of bioisosteric 5-sulfa-rutaecarpine derivatives
}

\section{Máté Bubenyák, ${ }^{\mathrm{a} *}$ Mária Takács, ${ }^{\mathrm{a}}$ Balázs Blazics, ${ }^{\mathrm{b}}$ Ákos Rácz, ${ }^{\mathrm{a}}$ Béla Noszál, ${ }^{\mathrm{a}}$ László Püski, József Kökösi, ${ }^{a}$ and István Hermecz ${ }^{c}$}

${ }^{a}$ Department of Pharmaceutical Chemistry, Semmelweis University, Högyes E. u. 9., Budapest 1092, Hungary

${ }^{b}$ Department of Pharmacognosy, Semmelweis University, Utlöi út 26., Budapest 1085, Hungary

${ }^{c}$ Chinoin Pharmaceutical and Chemical Works Ltd., POB 110, Budapest 1325, Hungary

E-mail: bmate@gyok.sote.hu

\begin{abstract}
Rutaecarpine (Evodia rutaecarpa) derivatives were synthesized by bioisosteric replacements of the quinazolone moiety of the pentacyclic system with benzothiadiazine 1,1-dioxide. Syntheses were performed efficiently by formation of phenylhydrazones via active methylene group transformations of pyrrolo- and pyrido[1,2-b]1,2,4-benzothiadiazine 5,5-dioxides, and subsequent Fischer-indolization. Preliminary testing of compound $\mathbf{3}$ showed cytotoxic activity against HeLa cells and apoptosis inducing effect.
\end{abstract}

Keywords: Alkaloids, antitumor agents, benzothiadiazine, bioisosteric replacements, luotonin A, rutaecarpine

\section{Introduction}

Fused heterocyclic compounds have traditionally been a starting-point for the design of novel anticancer agents, and current interest is in the development of bioisosteric approaches to new ring systems. ${ }^{1}$ Traditional Chinese medicine has a unique position among traditional medicines as it provides new and safer bioactive lead structures with antitumour activity. ${ }^{2}$

Rutaecarpine-type alkaloids form an important class of indolopyridoquinazolinone heterocycles and belong to the subgroup of quinazoline-type alkaloids isolated from the heartwood and the fruit of numerous plants and trees of the Rutaceae family., ${ }^{3,45}$ Their extracts have long been used as important remedies in Chinese traditional medicine. "Wu-Chu-Yu", the dried unripe fruit of Evodia rutaecarpa, a Chinese herbal drug showed remarkable efficacy in headache, cholera, dysentery, worm infestations and post partum disturbances. ${ }^{7}$ Rutaecarpine $\mathbf{1}$ and evodiamine 2 (Figure 1), the major quinazolinocarboline alkaloids isolated from $E$. rutaecarpa showed various pharmacological activities in earlier studies ${ }^{8,9}$ and notable examples 
include antimetastatic, antiproliferative, and apoptotic effect. ${ }^{10,11}$ Recent pharmacological researches proved that evodiamine stabilizes the topoisomerase-I-DNA complex and induces caspase- 3 activity. ${ }^{12}$
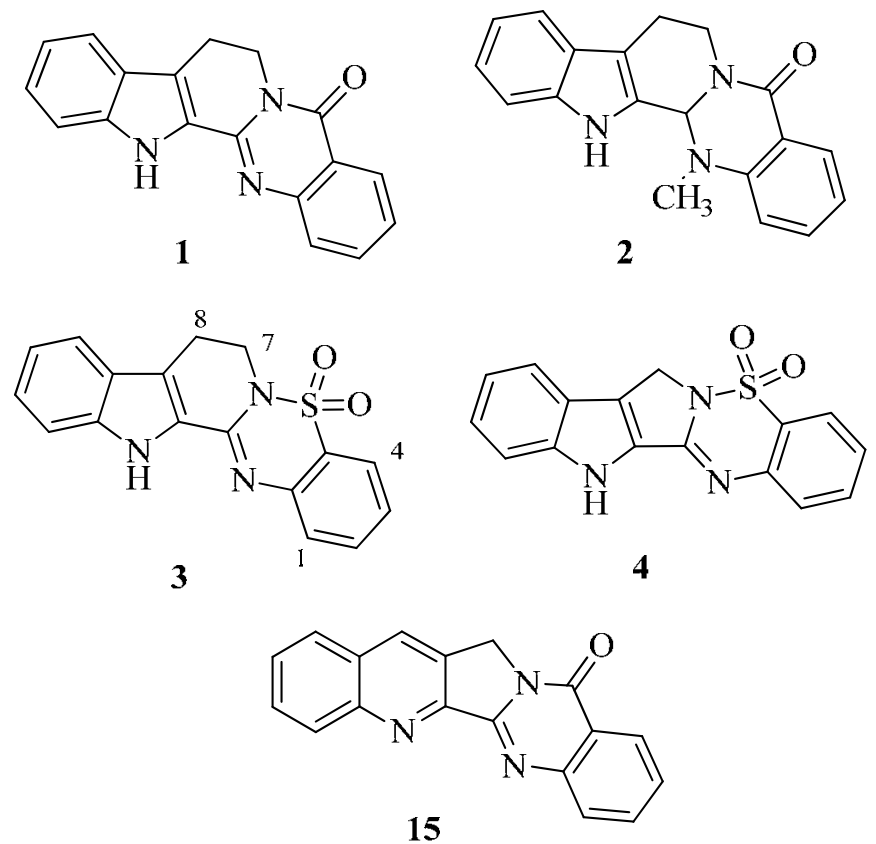

Figure 1. Structure of bioisosteric analogues 3 and 4 of rutaecarpine 1, evodiamine 2 and luotonin A 15.

Quinazoline and 1,2,4-benzothiadiazine 1,1-dioxide are considered as bioisosteric ring systems, and numerous attempts to vary the size of the ring or change their functional groups have been made in order to modify biological activity and selectivity. ${ }^{13}$

1,2,4-Benzothiadiazine 1,1-dioxides are used as antihypertensive, diuretic, antidiabetic, glutaminergic neuromodulators ${ }^{14,15}$ and K-channel inhibitors, ${ }^{16}$ yet the ring system has also been known for its anti-microbial and anti-tubercular activity. ${ }^{17,18}$ Additionally, this class of compounds has been proved to inhibit hepatitis $\mathrm{C}$ virus (HCV) replication effectively in cell based replication systems with no apparent cytotoxicity. ${ }^{19}$ Anticancer agents containing the 1,2,4-benzothiadiazine 1,1-dioxide ring system also exhibit potent antiviral activity. ${ }^{20}$

Several hybrid compounds where quinazoline moiety or its bioisosteric analogue was built in to structures of well-known antitumour agents have been designed, synthesized and evaluated for biological activity in the past few years. ${ }^{21}$ Recently, we have been involved in the development of new synthetic strategies ${ }^{22}$ for the preparation of new pentacyclic ring systems and also in the design of structurally modified quinazolinocarbolines and their hybrids for the development of more potent anticancer agents. ${ }^{23,24}$ 


\section{Results and Discussion}

Here we report the synthesis of rutaecarpine analogues 3,4 which were formed by replacing the quinazoline moiety of the natural alkaloid with the 1,2,4-benzothiadiazine 1,1-dioxide partial structure. Rutaecarpine 1 has become a popular synthetic target, and a great variety of its synthetic solutions has been published. ${ }^{5}$ Several total syntheses of $\mathbf{2}$ have also been reported ${ }^{25}$ including our original synthetic approaches. ${ }^{26}$

The preparation of tricyclic fused 1,2,4-benzothiadiazine 1,1-dioxide containing five- and six- membered polymethylene condensed heterocycles was accomplished in two independent ways following the synthetic sequences depicted in Scheme 1. The starting material, orthanilic acid $\mathbf{5}$ was treated with semicyclic iminoethers $\mathbf{6 a , b}$ in methanol at ambient temperature for $96 \mathrm{~h}$ and $72 \mathrm{~h}$, respectively and 2-amidino-phenyl-sulfonic acids $\mathbf{7 a , b}$ were obtained with moderate yield.

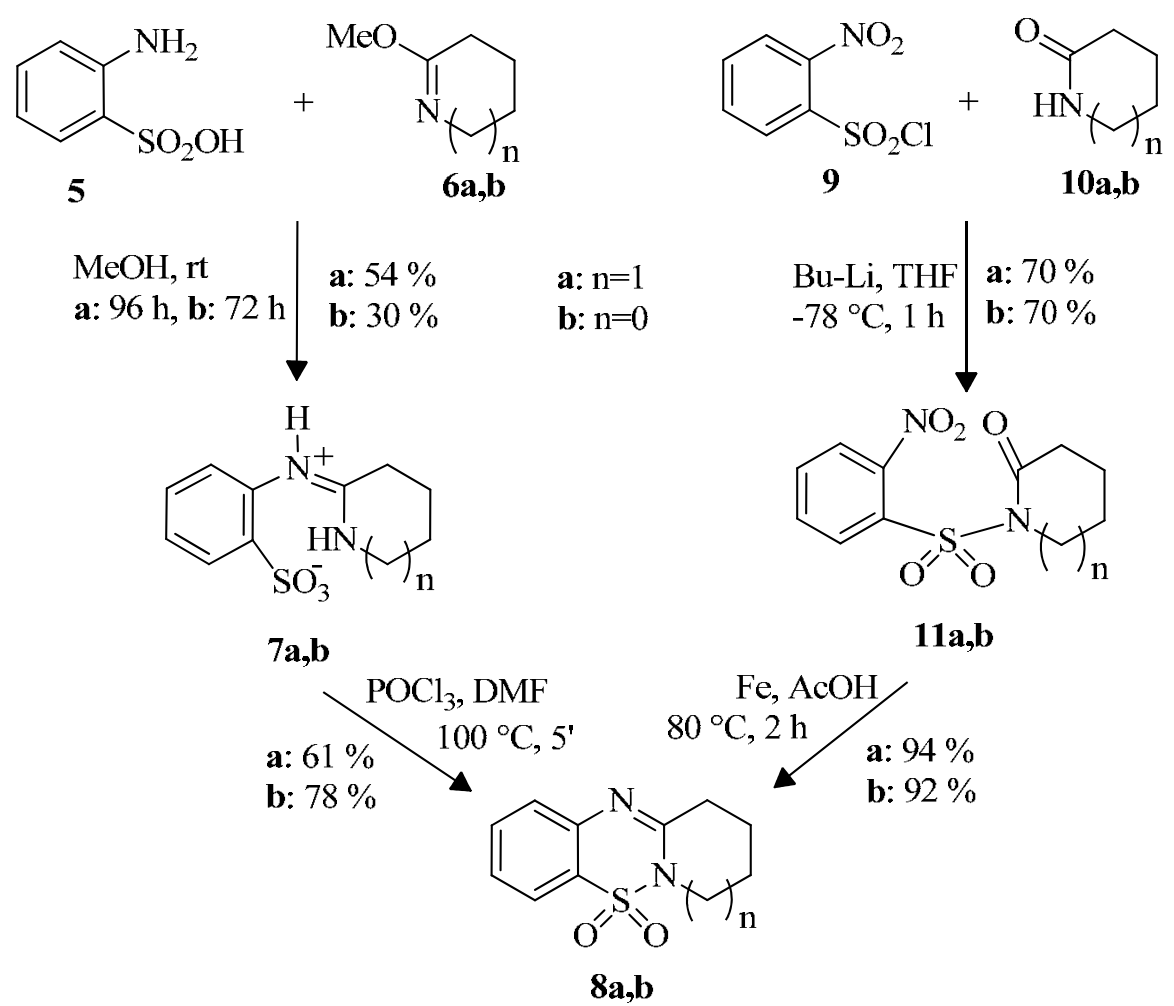

Scheme 1. Synthesis of tricyclic 1,2,4-benzothiadazines 8a,b.

Cyclisation of the compounds $\mathbf{7 a , b}$ to tricycles $\mathbf{8 a}, \mathbf{b}$ was performed by treatment with large excess of phosphorous oxychloride at $100{ }^{\circ} \mathrm{C}$ for $5 \mathrm{~min}$ in moderate yields. In the alternative way 2-nitrobenzenesulfonyl chloride 9 was reacted with 2-pyrrolidone 10b or $\delta$-valerolactam 10a in THF in presence of buthyl-lithium and led to intermediers 11a,b. ${ }^{29}$ The subsequent reduction of the nitro group provided the tricycles $\mathbf{8 a}, \mathbf{b}$ in excellent yield. 
The active methylene reactivity of tricyclic compound $\mathbf{8 b}$ was characterised by the kinetic constant $\left(\mathrm{k}=1.78 \cdot 10^{-4} \mathrm{1} / \mathrm{s}\right)$ of acid catalysed hydrogen-deuterium exchange rate. The experimental data indicate decreased reactivity of the sulfa compounds compared to that of analogous tetrahdropyridoquinazolone $\left(\mathrm{k}=4.29 \cdot 10^{-3} 1 / \mathrm{s}\right){ }^{28}$

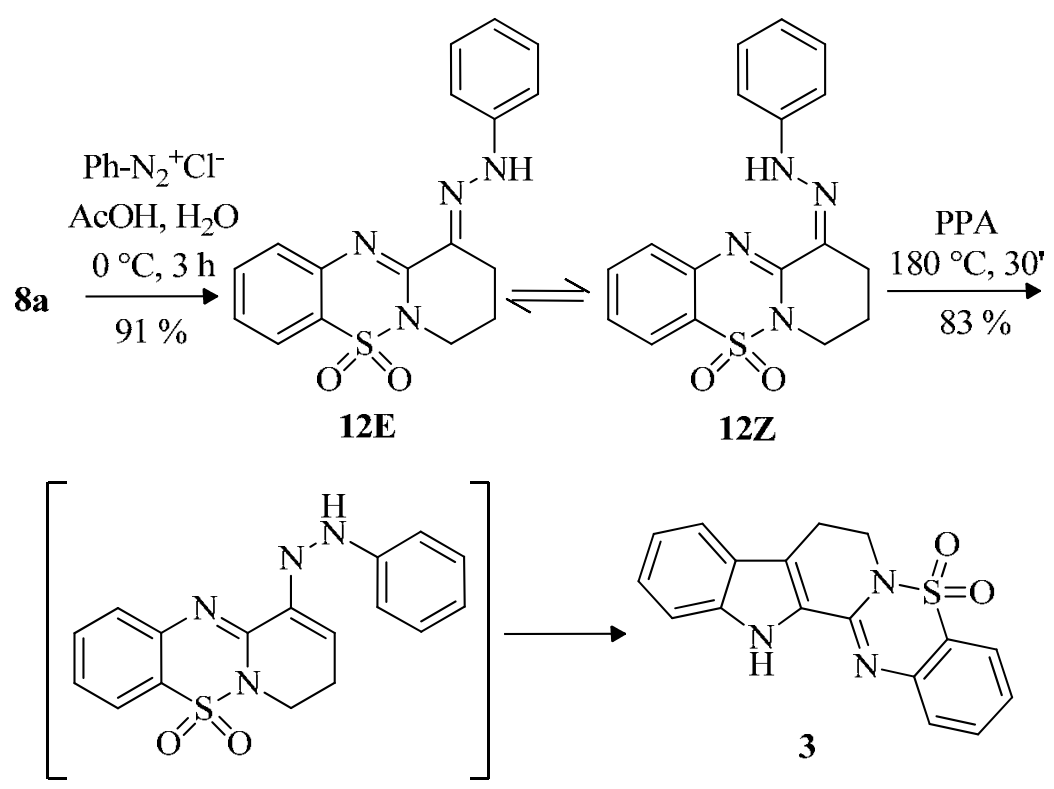

Scheme 2. Synthesis of 5-sulfa-rutaecarpine 3.

Reaction of the active methylene group at position 4 of compound $\mathbf{8 a}$ with phenyldiazonium chloride resulted in 6-phenylhydrazono derivative 12 (Scheme 2.). This type of reaction has been applied to similarly positioned active methylene groups earlier. ${ }^{22,26}$ Direct azocoupling reaction failed in the case of the five-membered tricyclic compound $\mathbf{8 b}$ which had decreased methylene group reactivity at the position 3 . In order to increase reactivity on the C-3 carbon atom, formylation was accomplished to introduce an activating substituent (Scheme 3.).

Vilsmeier-Haack formylation of $\mathbf{8 b}$ using two equivalents of phosphorous oxychloride in DMF at $60{ }^{\circ} \mathrm{C}$ for 3 hours gave the 3-dimethylaminomethylene derivative 13 in $94 \%$ yield. Only the sterically more favourable E geometric isomer is present in the DMSO- $d_{6}$ solution, as proved by the NOE between the N-methyl and 2-methylene groups. Japp-Klingemann reaction ${ }^{27}$ of $\mathbf{1 3}$ with phenyldiazonium chloride in acetic acid solution $\left(0^{\circ} \mathrm{C}, 3 \mathrm{~h}\right)$ resulted in the phenylhydrazone derivative 14 in $89 \%$ yield. 


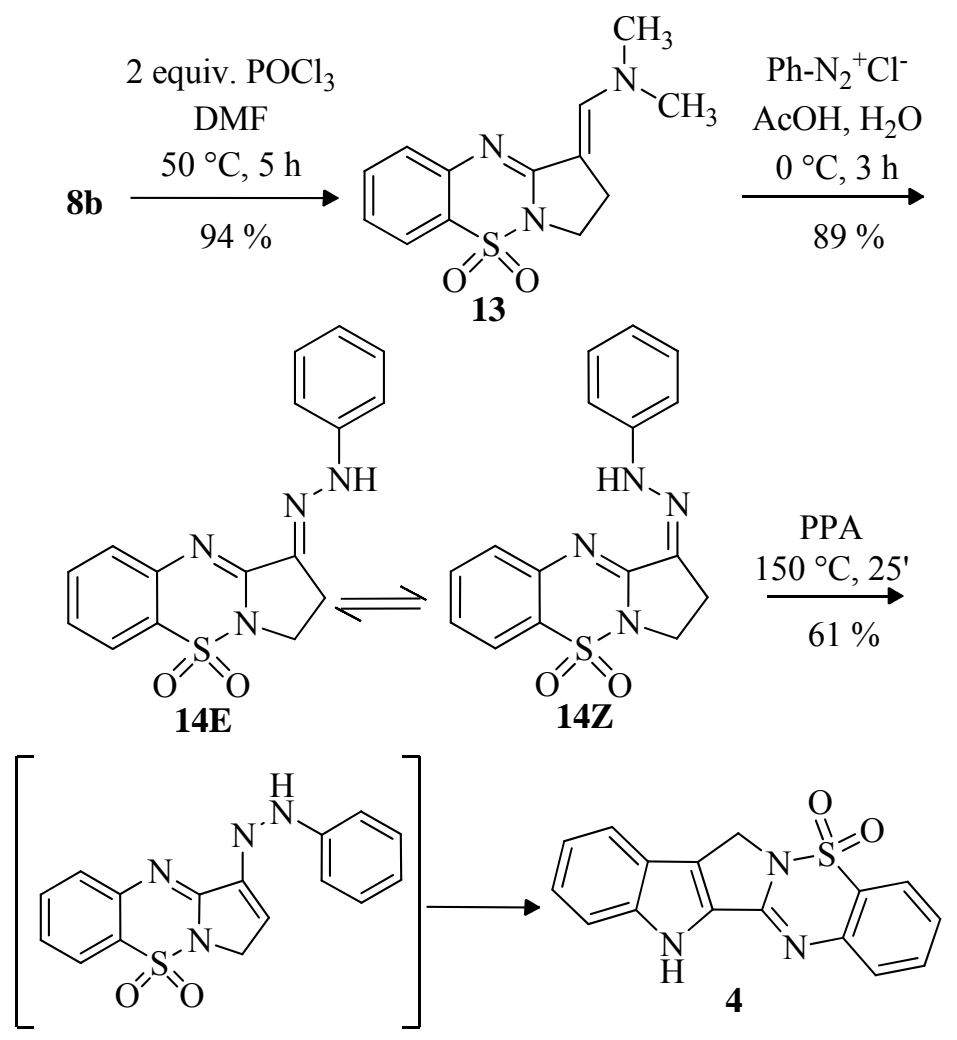

Scheme 3. Synthesis of 5-sulfa-8-norrutaecarpine 4.

The phenylhydrazono derivatives 12, 14 exhibit a solvent dependent E/Z geometric isomerism, and indicate low activation energy of the rotation around the exo cyclic $\mathrm{C}(6)=\mathrm{N}$ double bond. In $\mathrm{CDCl}_{3}$ the sterically more crowded $\mathrm{Z}$ form predominates $(\sim 100 \%)$, which is stabilized by an internal hydrogen bond between the amino group and ring nitrogen atom. The sterically more favourable $\mathrm{E}$ isomer is more abundant in DMSO- $d_{6}$, as the solvent forms a stronger hydrogen bridge with the amino group than in $\mathrm{CDCl}_{3}$.

The ${ }^{13} \mathrm{C}$ chemical shifts of compounds 12 and 14 were assigned using data for analogous rutecarpine synthesis intermediers and the assignment was also confirmed by DEPT-135 spectra. Fischer indolization of phenylhydrazono compounds $\mathbf{1 2}$ and $\mathbf{1 4}$ was carried out in polyphosphoric acid (PPA) $\left(12: 180{ }^{\circ} \mathrm{C}, 30 \mathrm{~min}, 14: 150{ }^{\circ} \mathrm{C}, 25 \mathrm{~min}\right)$ to give pentacyclic 8,13 dihydro-7H-indolo[2',3':3,4]pyrido[1,2- $b][1,2,4]$ benzothiadiazine-5,5-dioxide $\quad 3$ and 7,12dihydroindolo[2',3':3,4]pyrrolo[1,2-b][1,2,4]benzothiadiazine-5,5-dioxide 4 in good yields (see Schemes 2 and 3). The crude product of compound 4 was purified by preparative thin layer chromatography. The resulting compounds can also be named as 5-sulfa-rutecarpine 3 and 5sulfa-8-norrutaecarpine 4. These constitute new heterocylic ring systems, which contain bioisosteric structural features common with the bioactive natural alkaloidsrutaecarpine $\mathbf{1}$ and luotonin A 15, respectively. Luotonin A 15 is a new natural lead compound for development of camptothecin-like anticancer agents. $^{30,31}$ 
Preliminary apoptotic studies were performed as follows: To test the effects of rutaecarpine 1, evodiamine 2 and 5-sulfa-rutaecarpine 3, HeLa cells were incubated with $10^{-6} \mathrm{~mol} / \mathrm{L}$ solutions of the compounds for 72 hours and nucleosomal DNA fragmentation, a marker of apoptotic cell death, was analyzed by flow cytometry. The percent of apoptotic cells corresponding to the subG1 phase was found to be $14.5 \pm 2.80$ with rutaecarpine 1, 33.6 \pm 0.68 with evodiamine 2, and $29.2 \pm 4.91$ with 5 -sulfa-rutaecarpine 3 . Cells were also incubated with etoposide as a positive control, and $15.4 \pm 1.86$ percent was observed to undergo apoptosis.

\section{Experimental Section}

General. Melting points were measured with a digital melting point apparatus and are uncorrected. NMR experiments of all compounds (except compounds 7a,b) were carried out on a $600 \mathrm{MHz}$ NMR spectrometer equipped with a dual 5-mm inverse-detection gradient (IDPFG) probehead. In case of structure identifications, standard pulse sequences and processing routines were used. ${ }^{1} \mathrm{H}$ and ${ }^{13} \mathrm{C}$ chemical shifts were referenced to internal TMS $(\delta=0.000 \mathrm{ppm})$ or to the residual solvent signal unless otherwise stated. The probe temperature was maintained at $298 \mathrm{~K}$ and standard $5 \mathrm{~mm}$ NMR tubes were used in all experiments.

NMR spectra of 7a,b in $\mathrm{D}_{2} \mathrm{O}$ were acquired at $25^{\circ} \mathrm{C}$ on NMR spectrometers operating at 500 and $800 \mathrm{MHz}$ proton frequencies, both equipped with cryogenic $\mathrm{HCN}$ probeheads. ${ }^{1} \mathrm{H}$ and ${ }^{13} \mathrm{C}$ chemical shifts were referenced to internal sodium 3-trimethylsilyl-propanesulfonate (DSS). Standard pulse sequences and processing routines were applied.

Single-tube ${ }^{1} \mathrm{H}$ NMR-pH titrations were conducted at $2 \mathrm{mM}$ concentration, $25{ }^{\circ} \mathrm{C}$ and $0.15 \mathrm{M}$ ionic strength $(\mathrm{NaCl})$ in $\mathrm{H}_{2} \mathrm{O} / \mathrm{D}_{2} \mathrm{O} 9 / 1$ solvent. For molecules $\mathbf{7 a}$, b, in situ $\mathrm{pH}$ monitoring was accomplished by using trimethylamine, TRIS and imidazole ( $1 \mathrm{mM}$ each). For compounds 8a,b protonating at $\mathrm{pH}<7$, acetic, chloroacetic and dichloroacetic acids ( $1 \mathrm{mM}$ each) were applied as $\mathrm{pH}$ indicators. Degradation products were observed during the titration of $\mathbf{8 b}$, studies on its $\mathrm{pH}$ dependent degradation kinetics are currently in progress.

LC-MS conditions: For mass spectrometric analysis of compounds $\mathbf{3}$ and $\mathbf{4}$ a triple quadrupole equipped with an electrospray ionization source (ESI) was used coupled to a HPLC system. Full mass scan spectra were recorded in positive ion mode over an $\mathrm{m} / \mathrm{z}$ range of 50-400 dalton (500 msec cycletime). ESI conditions were as follows: temperature: $350{ }^{\circ} \mathrm{C}$, nebulizer pressure: 40 psi $\mathrm{N}_{2}$, drying gas flow: $9 \mathrm{~L} / \mathrm{min} \mathrm{N}_{2}$, fragmentor voltage: $100 \mathrm{~V}$, capillary voltage: $3500 \mathrm{~V}$. High purity nitrogen was used as collision gas during CID experiments and the collision energy was 30, 40 and $45 \mathrm{eV}$. Chromatographic conditions were as follows: a dead zero volume was used, with $100 \%$ acetonitrile as eluent. Injection volume was $3 \mu \mathrm{L}$.

High-resolution mass spectra with electrospray ionization (HRMS-ESI) of all the other new compounds were recorded on a hydrid mass spectrometer consisting of a Linear Ion Trap Mass Spectrometer, combined with a Fourier Transform Ion Cyclotron Resonance Mass Spectrometer. 
The reaction progress was monitored by thin layer chromatography (TLC) on silica gel plates, visualized with UV light and the plates were developed using Dragendorff reagent stains.

To assess nucleosomal DNA fragmentation, HeLa cells were treated with $10^{-6} \mathrm{M}$ of each compound for 72 hours. Cells were then trypsinized, counted and $2 \cdot 10^{5}$ cells were fixed with 1 $\mathrm{ml}$ of $-20{ }^{\circ} \mathrm{C}, 70 \%$ ethanol. Samples were kept at room temperature for 30 minutes, and afterwards they were stored at $-20^{\circ} \mathrm{C}$, or processed. To extract fragmented DNA, samples were centrifuged at $450 \mathrm{~g}$ for 5 minutes, supernatants were discarded and the cell pellets were resuspended in $300 \mu \mathrm{l}$ extraction buffer $\left(200 \mathrm{mM} \mathrm{Na}_{2} \mathrm{HPO}_{4}\right.$ containing $0.1 \mathrm{mg} / \mathrm{ml}$ RNAse A, adjusted to $\mathrm{pH} 7.8$ with $200 \mathrm{mM}$ citric acid). Cells were incubated with the extraction buffer for 15 minutes at room temperature, and then $3 \mu \mathrm{l}$ propidium iodide solution $(1 \mathrm{mg} / \mathrm{ml})$ was added to each sample. After another 15 minutes of incubation at room temperature, samples were analyzed by flow cytometry. Cell counts were plotted against the FL2 channel fluorescence intensity, and cells gated in the sub-G1 region were considered to be positive for apoptotic DNA fragmentation.

2-(Piperidin-2-ylideneamino)benzene-1-sulfonic acid (7a). To a suspension of $65.00 \mathrm{~g} \mathrm{(0.375}$ mol) of aniline-2-sulfonic acid 5 in $650 \mathrm{ml}$ of methanol was added dropwise $45.26 \mathrm{~g}(0.400 \mathrm{~mol})$ of 2-methoxy-3,4,5,6-tetrahydro-pyridine 6 a over the course of 30 minutes. The reaction mixture was stirred in absence of light at room temperature for 96 hours. The precipitated crystals were filtered and washed with cold methanol. The mother liquor was evaporated to about half volume and left to stand overnight in refrigerator. The precipitated second fraction was filtered and washed with cold methanol. The combined fractions were recrystallized from isopropanol to obtain $51.76 \mathrm{~g}$ (0.204 mol) of 2-(piperidin-2-ylideneamino)benzene-1-sulfonic acid (7a). Yield: $54.27 \%$, mp: $265{ }^{\circ} \mathrm{C}$, (dec.). UV: in EtOH: $\lambda_{\max }(\log \varepsilon)$ : 210.2 (4.093), 202.6 (4.176) nm. ${ }^{1} \mathrm{H}$ NMR $\left(\mathrm{D}_{2} \mathrm{O}, 500 \mathrm{MHz}\right) \delta 7.99(\mathrm{dd}, J=7.8,1.2 \mathrm{~Hz}, 1 \mathrm{H}), 7.69$ (ca.td, $\left.J=7.7,1.5 \mathrm{~Hz}, 1 \mathrm{H}\right), 7.62$ (ca.td, $J=7.7,1.2 \mathrm{~Hz}, 1 \mathrm{H}), 7.44$ (dd, $J=7.8,1.0 \mathrm{~Hz}, 1 \mathrm{H}), 3.30$ (br m, 2H), 2.84 (br m, 2H), 1.93-1.80 (br m, 4H) ppm; ${ }^{13} \mathrm{C}$ NMR ( $\left.\mathrm{D}_{2} \mathrm{O}, 125 \mathrm{MHz}\right) \delta 167.9,143.0,135.9,132.9,132.7,132.3$, 131.3, 44.4, 28.9, 22.9, 20.2 ppm. ESI-HRMS calcd. for $\mathrm{C}_{11} \mathrm{H}_{14} \mathrm{~N}_{2} \mathrm{O}_{3} \mathrm{~S}\left([\mathrm{M}+\mathrm{H}]^{+}\right) 255.07979$, found 255.07969. Elemental analysis: Anal. Calcd for $\mathrm{C}_{11} \mathrm{H}_{13} \mathrm{~N}_{2} \mathrm{O}_{3} \mathrm{~S}$ : C, 52.16; H, 5.18; N, 11.07. Found: C, 52.08; H, 5.21; N, 11.19 .

7,8,9,10-Tetrahydropyrido[1,2-b][1,2,4]benzothiadiazine-5,5-dioxide (8a). 1.00 g (3.932 mmol) of 7a was dissolved in $20 \mathrm{ml}$ of phosphoryl chloride $\left(\mathrm{POCl}_{3}\right)$ and a catalytic amount $(2$ drops) of dimethylformamide (DMF) was added to the solution. The mixture was heated on a steam bath at $90{ }^{\circ} \mathrm{C}$ for 5 minutes. Excess phosphoryl chloride was evaporated in vacuo and the residue was neutralized with $50 \%$ potassium carbonate solution $(10 \mathrm{ml})$. The aqueous phase was extracted with chloroform $(3 \times 20 \mathrm{ml})$, the organic extracts were combined, washed once with brine $(30 \mathrm{ml})$, dried over anhydrous sodium sulphate and the solvent was removed in vacuo. The solid product was purified by recrystallization from isopropanol to obtain $0.57 \mathrm{~g}$ of $7,8,9,10$ tetrahydropyrido[1,2- $b][1,2,4]$ benzothiadiazine-5,5-dioxide 8a. Yield: $61.35 \%, \mathrm{mp}: 70-71{ }^{\circ} \mathrm{C}$. UV: in EtOH $\lambda_{\max }(\log \varepsilon): 298.2$ (3.898), 272.4 (4.037), 264.4 (4.070), 212.0 (4.406) nm. ${ }^{1} \mathrm{H}$ NMR (600 MHz, DMSO-d $) \delta 1.95(\mathrm{dd}, J=6.6,7.2 \mathrm{~Hz}, 2 \mathrm{H}), 2.03(\mathrm{dd}, J=6.6,7.2 \mathrm{~Hz}, 2 \mathrm{H}), 2.86$ 
$(\mathrm{t}, J=6.6 \mathrm{~Hz}, 2 \mathrm{H}), 3.93(\mathrm{t}, J=4.2 \mathrm{~Hz}, 2 \mathrm{H}), 7.40(\mathrm{td}, J=1.2,7.8 \mathrm{~Hz}, 1 \mathrm{H}), 7.46(\mathrm{dd}, J=0.6,7.8$ $\mathrm{Hz}, 1 \mathrm{H}), 7.64(\mathrm{td}, J=1.2,7.8 \mathrm{~Hz}, 1 \mathrm{H}), 7.87$ (dd, $J=1.2,7.8 \mathrm{~Hz}, 1 \mathrm{H})$ ppm. HRMS (ESI): calcd for $(\mathrm{M}+\mathrm{H})^{+}\left(\mathrm{C}_{11} \mathrm{H}_{13} \mathrm{~N}_{2} \mathrm{O}_{2} \mathrm{~S}\right)$ requires $m / z$ 237.0698, found 237.0690. Elemental analysis: Anal. Calcd for $\mathrm{C}_{11} \mathrm{H}_{12} \mathrm{~N}_{2} \mathrm{O}_{2} \mathrm{~S}$ : C, 55.92; H, 5.12; N, 11.86. Found: C, 55.85; H, 5.24; N, 11.74.

10-Phenylhydrazono-8,9-dihydro-7H-pyrido[1,2-b][1,2,4]benzothiadiazine-5,5-dioxide (12). Phenyldiazonium chloride was produced from aniline $(0.9 \mathrm{~mL}, 10 \mathrm{mmol})$ in a conventional way: it was put into $1: 1$ diluted hydrochloric acid $(10 \mathrm{~mL})$ and $5 \mathrm{~mL}$ sodium nitrite $(0.69 \mathrm{~g}, 10 \mathrm{mmol})$ dissolved in water was added to it at $0{ }^{\circ} \mathrm{C}$. Consequently, this compound 8a $(2.36 \mathrm{~g}, 10 \mathrm{mmol})$ was dissolved in $20 \mathrm{~mL}$ acetic acid. The solution was added gradually to the tincture of phenyldiazonium chloride and the sodium acetate trihydrate $(6 \mathrm{~g})$ at $0{ }^{\circ} \mathrm{C}$. The reaction mixture was stirred for 24 hours at $0{ }^{\circ} \mathrm{C}$ and then it was diluted with water. The precipitated crystals were filtered and leached with water profoundly, dried and cleansed through boiling with isopropanol. Yield: 91\%, mp: $166-168{ }^{\circ} \mathrm{C}$ (dec.). UV: in $\mathrm{EtOH} \lambda_{\max }(\log \varepsilon)$ : 406.0 (4.095), 323.2 (3.560), 292.2 (3.612), 255.2 (3.988) nm. ${ }^{1} \mathrm{H}$ NMR (600 MHz, DMSO- $\left.d_{6}\right) \delta 2.18$ (t, $\left.J=4.8 \mathrm{~Hz}, 2 \mathrm{H}\right), 2.79$ $(\mathrm{t}, J=6.6 \mathrm{~Hz}, 2 \mathrm{H}), 4.05(\mathrm{t}, J=5.4 \mathrm{~Hz}, 2 \mathrm{H}), 7.07(\mathrm{t}, J=7.8 \mathrm{~Hz}, 1 \mathrm{H}), 7.39(\mathrm{t}, J=7.8 \mathrm{~Hz}, 2 \mathrm{H})$, $7.66(\mathrm{~m}$, overlap, 3H), $7.92(\mathrm{~m}$, overlap, 2H), $8.08(\mathrm{~d}, J=7.8 \mathrm{~Hz}, 1 \mathrm{H}), \delta \mathrm{NH} 11.04$ and 14.27 ppm; $E: Z$ ratio: 21:79. HRMS (ESI): calcd for $(\mathrm{M}+\mathrm{H})^{+}\left(\mathrm{C}_{17} \mathrm{H}_{17} \mathrm{~N}_{4} \mathrm{O}_{2} \mathrm{~S}\right)$ requires $\mathrm{m} / z$ 341.1072, found 341.1081. Elemental analysis: Anal. Calcd for $\mathrm{C}_{17} \mathrm{H}_{16} \mathrm{~N}_{4} \mathrm{O}_{2} \mathrm{~S}$ : C, 59.98; H, 4.74; N, 16.47. Found: C, 60.11; H, 4.68; N, 16.23.

8,13-Dihydro-7H-indolo[2',3':3,4]pyrido[1,2-b]benzothiadiazine-5,5-dioxide $\quad$ (3). 3.09 mmoles $(1.0 \mathrm{~g})$ of 12 was added to polyphosphoric acid $(10.0 \mathrm{~g})$ at $180{ }^{\circ} \mathrm{C}$ and the reaction mixture was stirred for 30 minutes. The reaction mixture was diluted with cold water $(100 \mathrm{ml})$ and the aqueous mixture was stirred for $1 \mathrm{~h}$. The precipitated crystals were filtered off, and washed with water. The resulting dried dark-green crude solid was extracted with chloroform $(3 \times 30 \mathrm{ml})$. The combined organic phase was evaporated and the residue was crystallised from isopropanol to yield 5-sulfa-rutaecarpine 3 in 83\%. Mp: 207-209 ${ }^{\circ} \mathrm{C}$. ${ }^{1} \mathrm{H}$ NMR (600 MHz, DMSO- $\left.d_{6}\right) \delta 3.24(\mathrm{t}, J=5.4 \mathrm{~Hz}, 2 \mathrm{H}), 4.28(\mathrm{t}, J=5.4 \mathrm{~Hz}, 2 \mathrm{H}), 7.12(\mathrm{t}, J=7.2 \mathrm{~Hz}, 1 \mathrm{H}), 7.31(\mathrm{t}, J$ $=7.2 \mathrm{~Hz}, 1 \mathrm{H}), 7.49(\mathrm{~d}, J=8.4 \mathrm{~Hz}, 1 \mathrm{H}), 7.54(\mathrm{t}, J=7.2 \mathrm{~Hz}, 1 \mathrm{H}), 7.63(\mathrm{t}, J=7.8 \mathrm{~Hz}, 1 \mathrm{H}), 7.67(\mathrm{t}$, $J=8.4 \mathrm{~Hz}, 1 \mathrm{H}), 7.83(\mathrm{td}, J=1.2,6.6 \mathrm{~Hz}, 1 \mathrm{H}), 7.97(\mathrm{dd}, J=0.6,7.2 \mathrm{~Hz}, 1 \mathrm{H}), 11.91(\mathrm{~s}, 1 \mathrm{H}, \mathrm{NH})$ ppm. ${ }^{13} \mathrm{C}$ NMR $\left(150 \mathrm{MHz}, \mathrm{DMSO}-d_{6}\right) \delta 20.7,40.9,112.6,119.3,120.0,120.2,121.5,124.9$, $125.5,126.1,126.5,126.6,127.1,134.3,138.7,142.4,144.6$ pmm. UV: in EtOH $\lambda_{\max }(\log \varepsilon)$ : 369.0 (4.081), 354.5 (4.183), 211.5 (4.122) nm. HRMS (ESI): calcd for $(\mathrm{M}+\mathrm{H})^{+}\left(\mathrm{C}_{17} \mathrm{H}_{14} \mathrm{~N}_{3} \mathrm{O}_{2} \mathrm{~S}\right)$ requires $m / z$ 324.0801, found 324.0815. Elemental analysis: Anal. Calcd for $\mathrm{C}_{17} \mathrm{H}_{13} \mathrm{~N}_{3} \mathrm{O}_{2} \mathrm{~S}$ : C, 63.14; H, 4.06; N, 13.00. Found: C, 63.02; H, 4.13; N, 12.84.

2-(Pyrrolidin-2-ylideneamino)benzene-1-sulfonic acid (7b). To a suspension of $88.90 \mathrm{~g}(0.513$ $\mathrm{mol}$ ) of aniline-2-sulfonic acid 5 in $850 \mathrm{ml}$ of methanol was added dropwise $54.52 \mathrm{~g}(0.550 \mathrm{~mol})$ of 2-methoxy-4,5-dihydro-3H-pyrrole $\mathbf{6 b}$ over the course of 30 minutes. The reaction mixture was stirred at room temperature for 72 hours. The precipitated crystals were filtered and washed with cold methanol. The mother liquor was evaporated to about half volume and left to stand overnight in refrigerator. The precipitated second fraction was filtered and washed with cold 
methanol. The combined fractions were recrystallized from isopropanol to obtain $60.77 \mathrm{~g}(0.253$ mol) of 2-(pyrrolidin-2-ylideneamino)benzene-1-sulfonic acid $\mathbf{7 b}$. Yield: $30.14 \%$, mp: $310{ }^{\circ} \mathrm{C}$, (dec.), (lit. mp: $210{ }^{\circ} \mathrm{C}^{32}$ ). UV in EtOH: $\lambda_{\max }\left(\log \varepsilon\right.$ ): 207.6 (4.299), 200.4 (4.314) nm. ${ }^{1} \mathrm{H}$ NMR $\left(\mathrm{D}_{2} \mathrm{O}, 800 \mathrm{MHz}\right) \delta 7.98$ (dd, $\left.J=7.8,1.3 \mathrm{~Hz}, 1 \mathrm{H}\right), 7.69$ (ca.td, $\left.J=7.7,1.5 \mathrm{~Hz}, 1 \mathrm{H}\right), 7.61$ (ca.td, $J$ $=7.7,1.2 \mathrm{~Hz}, 1 \mathrm{H}), 7.48(\mathrm{dd}, J=7.8,1.0 \mathrm{~Hz}, 1 \mathrm{H}), 3.66(\mathrm{br} \mathrm{m}, 2 \mathrm{H}), 3.10(\mathrm{br} \mathrm{m}, 2 \mathrm{H}), 2.27$ (br m, $2 \mathrm{H}) \mathrm{ppm} .{ }^{13} \mathrm{C}$ NMR $\left(\mathrm{D}_{2} \mathrm{O}, 200 \mathrm{MHz}\right) \delta 172.9,141.9,135.9,133.9,132.6,131.4,131.1,50.5$, 33.6, 23.0 ppm. FT-IR (KBr pellet): 3163, 2936, 1664, 1588, 1480, 1439, 1247, 1168, 1140, 1086, $1020 \mathrm{~cm}^{-1}$. ESI-HRMS calcd. for $\mathrm{C}_{10} \mathrm{H}_{12} \mathrm{~N}_{2} \mathrm{O}_{3} \mathrm{~S}\left([\mathrm{M}+\mathrm{H}]^{+}\right)$241.06414, found 241.06403. Elemental analysis: Anal. Calcd for $\mathrm{C}_{10} \mathrm{H}_{11} \mathrm{~N}_{2} \mathrm{O}_{3} \mathrm{~S}: \mathrm{C}, 50.20 ; \mathrm{H}, 4.64 ; \mathrm{N}, 11.72$. Found: $\mathrm{C}, 50.05$; $\mathrm{H}, 4.52 ; \mathrm{N}, 11.61$.

8,9-Dihydro-7H-pyrrolo[1,2-b][1,2,4]benzothiadiazine-5,5-dioxide (8b). $1.00 \mathrm{~g}$ (4.162 mmol) of $\mathbf{7 b}$ was dissolved in $20 \mathrm{ml}$ of phosphoryl chloride ( $\mathrm{POCl}_{3}$ ) and a catalytic amount ( 2 drops) of dimethylformamide (DMF) was added to the solution. The mixture was heated on a steam bath at $90^{\circ} \mathrm{C}$ for 5 minutes. Excess phosphoryl chloride was evaporated in vacuo and the residue was neutralized with $50 \%$ potassium carbonate solution $(10 \mathrm{ml})$. The aqueous phase was extracted with chloroform $(3 \times 20 \mathrm{ml})$, the organic extracts were combined, washed once with brine $(30 \mathrm{ml})$, dried over anhydrous sodium sulphate and the solvent was removed in vacuo. The solid crude product was purified by recrystallization from isopropanol to obtain $0.72 \mathrm{~g}$ of 2,3-dihydro- $1 \mathrm{H}$ pyrrolo[1,2-b][1,2,4]benzothiadiazine-5,5-dioxide 8b. Yield: $77.83 \%$, mp: $150.5-152.5{ }^{\circ} \mathrm{C}$. UV: in EtOH $\lambda_{\max }(\log \varepsilon): 295.6$ (3.551), 270.2 (3.746), 260.8 (3.790), $213.4(4.156) \mathrm{nm} .{ }^{1} \mathrm{H}$ NMR $\left(600 \mathrm{MHz}, \mathrm{CDCl}_{3}\right) \delta 2.23(\mathrm{~m}, 2 \mathrm{H}), 3.00(\mathrm{t}, J=7.8 \mathrm{~Hz}, 2 \mathrm{H}), 4.15(\mathrm{dd}, J=6.6,7.2 \mathrm{~Hz}, 2 \mathrm{H}), 7.43$ $(\mathrm{dd}, J=7.2,7.8 \mathrm{~Hz}, 1 \mathrm{H}), 7.48(\mathrm{~d}, J=8.4 \mathrm{~Hz}, 1 \mathrm{H}), 7.65(\mathrm{dd}, J=7.2,8.4 \mathrm{~Hz}, 1 \mathrm{H}), 7.96(\mathrm{~d}, J=7.8$ $\mathrm{Hz}, 1 \mathrm{H})$ ppm. HRMS (ESI): calcd for $(\mathrm{M}+\mathrm{H})^{+}\left(\mathrm{C}_{10} \mathrm{H}_{11} \mathrm{~N}_{2} \mathrm{O}_{2} \mathrm{~S}\right)$ requires $m / z$ 223.0541, found 223.0548. Elemental analysis: Anal. Calcd for $\mathrm{C}_{10} \mathrm{H}_{10} \mathrm{~N}_{2} \mathrm{O}_{2} \mathrm{~S}$ : C, 54.04; H, 4.54; N, 12.61. Found: C, 53.82; H, 4.47; N, 12.54 .

\section{9-Dimethylaminomethylene-8,9-dihydro-7H-pyrrolo[1,2-b][1,2,4]benzothiadiazine-5,5-}

dioxide (13). Phosphoryl chloride $\left(\mathrm{POCl}_{3}\right)(0.6 \mathrm{~g}, 4 \mathrm{mmol})$ was added dropwise to the dimethylformamide (DMF) solution $(5 \mathrm{~mL})$ of compound $\mathbf{8 b}(0.44 \mathrm{~g}, 2 \mathrm{mmol})$. The reaction mixture was stirred for 5 hours at $50^{\circ} \mathrm{C}$. After cooling, the solution was separated from the tarry secession of the dark reaction mixture and it was poured onto saturated, aqueous sodium bicarbonate solution $(35 \mathrm{~mL})$, then it was stirred for one hour at room temperature. Precipitated crystals were filtered off, washed with water, were dried and recrystallized from ethanol. Yield: $94 \%$. Mp: $175-177^{\circ} \mathrm{C}$ (dec.). ${ }^{1} \mathrm{H}$ NMR (600 MHz, DMSO- $\left.d_{6}\right) \delta 3.10(\mathrm{~s}, 6 \mathrm{H}), 3.14(\mathrm{t}, J=7.8 \mathrm{~Hz}$, 2H), 3.91 (t, $J=7.8 \mathrm{~Hz}, 2 \mathrm{H}), 7.21$ (td, $J=1.2,7.8 \mathrm{~Hz}, 1 \mathrm{H}), 7.26$ (d, $J=7.8 \mathrm{~Hz}, 1 \mathrm{H}), 7.44$ (s, $1 \mathrm{H}), 7.59$ (td, $J=1.2,7.8 \mathrm{~Hz}, 1 \mathrm{H}), 7.78(\mathrm{dd}, J=1.2,7.8 \mathrm{~Hz}, 1 \mathrm{H}) \mathrm{ppm}$. UV: in EtOH $\lambda_{\max }(\log \varepsilon)$ : 369.0 (4.307), 259.0 (3.683), 202.5 (4.086) nm. HRMS (ESI): calcd for $(\mathrm{M}+\mathrm{H})^{+}\left(\mathrm{C}_{13} \mathrm{H}_{16} \mathrm{~N}_{3} \mathrm{O}_{2} \mathrm{~S}\right)$ requires $m / z$ 278.0963, found 278.0970. Elemental analysis: Anal. Calcd for $\mathrm{C}_{13} \mathrm{H}_{14} \mathrm{~N}_{3} \mathrm{O}_{2} \mathrm{~S}$ : C, 56.51; H, 5.11; N, 15.22. Found: C, 56.45; H, 5.00; N, 15.08 .

9-Phenylhydrazono-8,9-dihydro-7H-pyrrolo[1,2-b][1,2,4]benzothiadiazine-5,5-dioxide (14). Phenyldiazonium chloride was produced from aniline $(0.9 \mathrm{~mL}, 10 \mathrm{mmol})$ in a conventional way: 
it was put into 1:1 diluted hydrochloric acid $(10 \mathrm{~mL})$ and $5 \mathrm{~mL}$ sodium nitrite $(0.69 \mathrm{~g}, 10 \mathrm{mmol})$ dissolved in water was added to it at $0{ }^{\circ} \mathrm{C}$. Consequently, compound $\mathbf{1 3}(2.77 \mathrm{~g}, 10 \mathrm{mmol})$ was dissolved in $20 \mathrm{~mL}$ acetic acid. The solution was added gradually to the tincture of phenyldiazonium chloride and the sodium acetate trihydrate $(6 \mathrm{~g})$ at $0{ }^{\circ} \mathrm{C}$. The reaction mixture was stirred for 24 hours at $0{ }^{\circ} \mathrm{C}$ and then it was diluted with water. The precipitated crystals were filtered and leached with water profoundly, dried and cleansed through boiling with isopropanol. Yield: 89\%, Mp: $188-192{ }^{\circ} \mathrm{C} .{ }^{1} \mathrm{H}$ NMR (600 MHz, DMSO- $\left.d_{6}\right) \delta 3.04(\mathrm{t}, J=7.2 \mathrm{~Hz}, 2 \mathrm{H}), 4.21(\mathrm{t}$, $J=7.2 \mathrm{~Hz}, 2 \mathrm{H}), 6.92(\mathrm{~m}, 1 \mathrm{H}), 7.32$ (m, overlap, 4H), 7.51 (td, $J=1.2,7.8 \mathrm{~Hz}, 1 \mathrm{H}), 7.64$ (d, $J=$ $7.8 \mathrm{~Hz}, 1 \mathrm{H}), 7.79(\mathrm{td}, J=1.8,7.8 \mathrm{~Hz}, 1 \mathrm{H}), 8.00(\mathrm{dd}, J=1.2,7.8 \mathrm{~Hz}, 1 \mathrm{H}), \delta \mathrm{NH} 10.18$ and 12.85 ppm, $E: Z$ ratio: 4:96. UV: in EtOH $\lambda_{\max }(\log \varepsilon)$ : 386.8 (4.505), 300.4 (3.894), 290.8 (3.907), 242.4 (4.318) nm. HRMS (ESI): calcd for $(\mathrm{M}+\mathrm{H})^{+}\left(\mathrm{C}_{16} \mathrm{H}_{15} \mathrm{~N}_{4} \mathrm{O}_{2} \mathrm{~S}\right)$ requires $m / z$ 327.0916, found 327.0922. Elemental analysis: Anal. Calcd for $\mathrm{C}_{16} \mathrm{H}_{14} \mathrm{~N}_{4} \mathrm{O}_{2} \mathrm{~S}$ : C, 58.88; H, 4.33; N, 17.18. Found: C, 68.62; H, 4.21; N, 16.97.

7,12-Dihydroindolo[2',3':3,4]pyrrolo[1,2-b]benzothiadiazine-5,5-dioxide (4). 3.07 mmoles $(1.0 \mathrm{~g})$ of 14 were added to polyphosphoric acid $(10.0 \mathrm{~g})$ at $150{ }^{\circ} \mathrm{C}$ and the reaction mixture was stirred for 25 minutes. The reaction mixture was diluted with cold water $(100 \mathrm{ml})$ and the aqueous mixture was stirred for $1 \mathrm{~h}$. The green precipitate were filtered off, and washed with water. Yield: 0.6 g, (61\%). M.p.: 214-218 ${ }^{\circ} \mathrm{C}$ (dec.). The resulting dried green crude solid was chromatographed: $35 \mathrm{mg}$ of crude product was dissolved in 2,5 ml of methanol-chloroform 1:1 solution and compounds were separated on preparative TLC plate $(20 \times 20 \mathrm{~cm}$, layer thickness 2 mm, Merck Art. 5717), eluting with benzene-methanol 4:1 mixture. Visualization: UV lamp, $\lambda=355 \mathrm{~nm}$. The chromatography yielded $20 \mathrm{mg}$ of tan solid, 5-sulfa-8-norrutaecarpine 4 as analytically pure sample $. \mathrm{R}_{\mathrm{f}}: 0.62, \mathrm{Mp}: \sim 220{ }^{\circ} \mathrm{C}$ (dec.). ${ }^{1} \mathrm{H}$ NMR $\left(600 \mathrm{MHz}, \mathrm{DMSO}-d_{6}\right) \delta 5.25$ $(\mathrm{s}, 2 \mathrm{H}), 7.21(\mathrm{t}, J=7.8 \mathrm{~Hz}, 1 \mathrm{H}), 7.38(\mathrm{t}, J=7.8 \mathrm{~Hz}, 1 \mathrm{H}), 7.52(\mathrm{~d}, J=8.4 \mathrm{~Hz}, 1 \mathrm{H}), 7.56(\mathrm{t}, J=7.8$ $\mathrm{Hz}, 1 \mathrm{H}), 7.62(\mathrm{~d}, J=8.4 \mathrm{~Hz}, 1 \mathrm{H}), 7.77(\mathrm{~d}, J=7.8 \mathrm{~Hz}, 1 \mathrm{H}), 7.83(\mathrm{t}, J=8.4 \mathrm{~Hz}, 1 \mathrm{H}), 8.06(\mathrm{~d}, J=$ $7.8 \mathrm{~Hz}, 1 \mathrm{H}), 12.47$ (s, 1H, NH) ppm. ${ }^{13} \mathrm{C}$ NMR (150 MHz, DMSO-d $\left.)\right) \delta 44.4,113.5,120.7$, $120.8,121.1,121.8,124.9,125.7,126.4,126.7,127.1,132.8,134.5,143.2,143.9,149.4$ ppm. UV: in EtOH $\lambda_{\max }(\log \varepsilon): 358.5$ (3.33), 343.5 (3.45), 305.5 (3.05), 201.0 (3.56) nm. HRMS (ESI): calcd for $(\mathrm{M}+\mathrm{H})^{+}\left(\mathrm{C}_{16} \mathrm{H}_{12} \mathrm{~N}_{3} \mathrm{O}_{2} \mathrm{~S}\right)$ requires $\mathrm{m} / \mathrm{z}$ 310.0650, found 310.0658. Elemental analysis: Anal. Calcd for $\mathrm{C}_{16} \mathrm{H}_{11} \mathrm{~N}_{3} \mathrm{O}_{2} \mathrm{~S}$ : C, 52.12; H, 3.59; N, 13.59. Found: C, 52.01; H, 3.46; N, 13.45 .

\section{Supplementary material}

MS and MS/MS spectra of compounds 3 and 4. NMR spectra of compounds 3, 4, 7a,b, 8a,b, 12, 13, and 14. 


\section{Acknowledgements}

Thanks to Erika Sziki, János Kóti (Richter Gedeon Plc.) and László Tölgyesi (Eötvös Lóránd University, Budapest) for the IR and HR mass spectra. This work was supported by the Hungarian Scientific Foundation (OTKA K73804).

\section{References}

1. Michael, J. P. Nat. Prod. Rep. 2009, 25, 166.

2. Heinrich, M.; Bremner, P. Curr. Drug Targets 2006, 7, 239.

3. 3.Yashima, Y.; Kashiwaki, K. J. Pharm. Soc., Japan 1915, 35, 1293.

4. Chu, J. H. Science Record, (China) 1951, 4, 279; Chem. Abstr. 1952, 46, 11589 b.

5. Lee, S. H.; Son, J-K.; Jeong, B. S.; Jeong, T-C.; Chang, H. W.; Lee E.-S.; Jahng, Y. Molecules 2008, 13, 272.

6. Tang, W.; Eisenbrand, G. In Chinese drugs of plant origin; Springer: Berlin, 1992; 509-514.

7. Li, H. T.; Hong, H.-I. Yao Hseun Pao 1966, 13, 265; Chem. Abstr. 1966, 65, 3922c.

8. Hibino, S.; Choshi, T. Nat. Prod. Rep. 2001, 18, 66.

9. Deng, P.-Y.; Ye, F.; Cai, W.-J.; Tan, G.-S.; Hu, C.-P.; Deng, H.-W.; Li, Y.-J. J. Hypertens. 2004, 22, 1819.

10. Jiang, J.; Hu, C. Molecules 2009, 14, 1852.

11. Fei, X. F.; Wang, B. X.; Li, T. J.; Tashiro, S.-I.; Minami, M.; Xing, D. J.; Ikejima, T. Cancer Science 2003, 94, 92.

12., A. L.; Chang, W. S.; Chen, L. M.; Lee, C. M.; Chen, C. E.; Lin, C. M.; Hwang, J. L. Molecules 2009, 14, 1342.

13. (a) Boverie, S.; Antoine, M.-H.; Somers, S.; Becker, B.; Sebille, S.; Ouedraogo, R.; Counerotte, S.; Pirotte, B.; Lebrun, P.; De Tullio, P. J. Med. Chem. 2005, 48, 3492. (b) Mannhold, R. Med. Research Reviews 2004, 24, 213. (c) Lebrun, P.; Arkhammar, P.; Antoine, M.-H.; Nguyen, Q.-A.; Hansen, J. B.; Pirotte, B. Diabetologia 2000, 43, 723. (d) US Patent 3257395; June 21, 1966; Rudolf G. Griot, Sandoz Inc., Hanover, N. J. Chem. Abstr. 1966, 65, 7201b and references cited therein.

14. Cordi, A.; Spedding, M.; Serkiz, B.; Lepagnol, J.; Desos, P.; Morain, P. U.S. Patent 5536719, July 16, 1996; Chem. Abstr. 1996, 124, 261085.

15. Sarisky, R. T. J. Antimicrob. Chemother. 2004, 54, 14.

16. (a) Di Bella, M.; Monzani, A.; Andrisano, M. G.; Fabio, U.; Quaglio, G. P. Farmaco. [Sci]. 1983, 38, 466. (b) Di Bella, M.; Monzani, A.; Andrisano, M. G.; Fabio, U.; Quaglio, G. P. Farmaco. Sci. 1979, 34, 189.

17. Kamal, A.; Reddy, K. S.; Ahmed, S. K.; Khan, M. N. A.; Sinha, R. K.; Yadava, J. S.; Arora, S. K. Bioorg. Med. Chem. 2006, 14, 650. 
18. (a) Impagnatiello, F.; Oberto, A.; Longone, P.; Costa, E.; Guidotti, A. Proc. Natl. Acad. Sci. U.S.A. 1997, 94, 7053. (b) Phillips, D.; Sonnenberg, J.; Arai, A.; Vaswani, R.; Krutzik, P. O.; Kleisli, T.; Kessler, M.; Granger, R.; Lynch, G.; Chamberlin, A. R. Bioorg. Med. Chem. 2002, 10, 1229.

19. Kamal, A.; Khan, M. N. A.; Reddy, K. S.; Ahmed, S. K.; Kumar, M. S.; Juvekar, A.; Sen, S.; Zingde, S. Bioorg. Med. Chem. Lett. 2007, 17, 5345.

20. (a) Kamal, A.; Khan, M. N.; Srikanth, Y. V.; Rajesh, S. V. Chem. Biol. Drug Des. 2009, 73, 687. (b) Tang, A.; Lien, E. J.; Lai, M. M. C. J. Med. Chem. 1985, 28, 1103.

21. (a) Craggand, G. M.; Newman, D. J. Phytochem. Rev. 2009, 8, 313. (b) Singh, P.; Kaur, M.; Verma, P. Bioorg. Med. Chem. Lett. 2009, 19, 3054. (c) Natarajan, A.; Guo, Y.; Harbinski, F.; Fan, Y.-H.; Chen, H.; Luus, L.; Diercks, J.; Aktas, H.; Chorev, M.; Halperin, J. A. J. Med. Chem. 2004, 47, 4979.

22. (a) Bubenyák, M.; Pálfi, M.; Takács, M.; Béni, Sz.; Szökő, É.; Noszál, B.; Kökösi, J. Tetrahedron Lett. 2008, 49, 4937. (b) Bubenyák, M.; Noszál, B.; Kóczián, K.; Takács, M.; Béni, Sz.; Hermecz, I.; Kökösi, J. Tetrahedron Lett. 2008, 49, 5711.

23. Huber, K.; Bracher, F. Z. Naturforsch. 2007, 62b, 1313.

24. Kiss, Á.; Kökösi, J.; Rotter, R.; Hermecz, I. Tetrahedron 2000, $56,7987$.

25. Selected articles: (a) Bergman, J.; Bergman, S. Heterocycles 1981, 16, 2347. (b) Mohanta, P. K.; Kim, K. Tetrahedron Lett. 2002, 43, 3993. (c) Lee, E. S.; Park, J. G.; Jahng, Y. Tetrahedron Lett. 2003, 44, 1883. (d) Mhaske, S. B.; Argade, N. P. Tetrahedron 2004, 60, 3417. (e) Hamid, A.; Elomri, A.; Daïch, A. Tetrahedron Lett. 2006, 47, 1777. (f) Lee, C-S.; Liu, C-K.; Chiang, Y-L.; Cheng, Y-Y. Tetrahedron Lett. 2008, 49, 481 and references cited therein.

26. (a) Kökösi, J.; Hermecz, I.; Szász, Gy.; Mészáros, Z. Tetrahedron Lett. 1981, 22, 4861. (b) Kökösi, J.; Szász, Gy.; Hermecz, I. Tetrahedron Lett. 1992, 33, 2995. (c) Kökösi, J.; Hermecz, I.; Podányi, B.; Szász, Gy.; Mészáros, Z. J. Heterocycl. Chem. 1985, 22, 1373. (d) Hermecz, I.; Kökösi, J.; Horváth, Á.; Podányi, B.; Vasvári-Debreczy, L.; Szász, G.; Mészáros, Z. J. Heterocycl. Chem. 1987, 24, 1045. (e) Hermecz, I.; Kökösi, J.; VasváriDebreczy, L.; Horváth, Á.; Podányi, B.; Szász, Gy.; Mészáros, Z. F. E. CS. Int. Conf. Chem. Biotechnol. Biol. Act. Nat. Prod., [Proc], $3^{\text {rd }} 1985$ (Pub. 1987) 5, 332; Chem. Abstr. 1989, 110, 231939. (f) Hermecz, I.; Kökösi, J.; Podányi, B.; Szász, Gy. Heterocycles 1994, 37, 903.

(g) Hermecz, I.; Kökösi, J.; Podányi, B.; Likó, Zs.; Tetrahedron 1996, 52, 7789.

27. Grant, T. N.; Benson, C. L.; West, F. G. Org. Lett. 2008, 10, 3985.

28. Hermecz, I.; Vasváry-Debreczy, L. Adv. Heterocycl. Chem. 1986, 39, 356.

29. Philips, R. R. Org. React. 1959, 10, 143.

30. Ma, Z. Z.; Hano, Y.; Nomura, T.; Chen, Y.-J. Heterocycles 1999, 51, 1593.

31. Mhaske, S. B.; Argade, N. P. Tetrahedron 2006, 62, 9787.

32. Ranga, S. P.; Daga, K.; Gaur, S.; Mehta, R. K. Indian J. Chem. 1987, 26A, 526. 